\title{
Analisis Minat Belajar Siswa Menggunakan Media Pembelajaran E-comic Aritmatika Sosial Dimasa Pandemi Covid-19
}

\author{
Yosse Andreas Batu-Bara ${ }^{1)}$, Zetriuslita ${ }^{2)}$, Agus Dahlia $^{3)}$, Leo Adhar Effendi ${ }^{4)}$ \\ ${ }^{1,2,3,4}$ Program Studi Pendidikan Matematika, Universitas Islam Riau (UIR) \\ email: ${ }^{1}$ yossebb@student.uir.ac.id \\ 2zetriuslita@edu.uir.ac.id \\ 3agus.dahlia@edu.uir.ac.id \\ ${ }^{4}$ leo.ae@edu.uir.ac.id
}

\begin{abstract}
Abstrak
Pandemi Covid-19 menjadi trending topik pembicaraan satu tahun belakangan sampai sekarang ini, pandemi ini telah mengubah berbagai aspek kehidupan manusia saat ini, khususnya dalam dunia pendidikan. Hal ini meyebabkan kegagalan siswa dalam memahami konsep matematika dan kurangnya minat belajar siswa. Penelitian ini bertujuan untuk mendeskripsikan minat belajar siswa terhadap penggunaan media E-comic pada materi aritmatika sosial selama masa pandemi Covid-19. Penelitian ini merupakan penelitian kuantitatif deskriptif. Sampel penelitian adalah siswa kelas VII SMP yang terdiri dari 15 orang siswa yang di ambil secara random . instrumen yang digunakan dalam penelitian ini yaitu instrument non-test berupa angket minat belajar siswa yang disebarkan menggunakan Google Form pada pembelajaran aritmatika sosial menggunakan E-comic yang terdiri dari 20 pernyataan sebagai acuan untuk mengetahui minat belajar siswa dalam penggunaan media E-comic. Teknik analisis data yang digunakan dalam penelitian ini adalah analisis deskriptif kuantitatif. Hasil penelitian ini menunjukkan penggunaan media pembelajaran E-comic efektif terhadap minat belajar siswa di masa pandemi Covid-19 dengan hasil persentase $80,67 \%$ tergolong kriteria sangat tinggi. Sehingga media pembelajaran E-comic sangat efektif digunakan sebagai media pembelajaran matematika untuk meningkatkan minat belajar siswa di masa pandemi Covid-19.
\end{abstract}

Kata Kunci: analisis, E-comic, aritmatika sosial, pandemi covid-19

\begin{abstract}
The Covid-19 pandemic has become a trending topic of conversation for the past year until now, this pandemic has changed various aspects of human life today, especially in the world of education. This causes students' failure to understand mathematical concepts and students' lack of interest in learning. This study aims to describe students' learning interest in the use of E-comic media in social arithmetic material during the Covid-19 pandemic. This research is a descriptive quantitative research. The sample of the research was the seventh grade students of SMP which consisted of 15 students who were taken randomly. The instrument used in this study is a non-test instrument in the form of a student learning interest questionnaire distributed using Google Form in social arithmetic learning using E-comic which consists of 20 statements as a reference to determine students' interest in learning in the use of E-comic media. The data analysis technique used in this research is quantitative descriptive analysis. The results of this study indicate that the use of E-comic learning media is effective on student learning interest during the Covid-19 pandemic with the percentage results $80.67 \%$ classified as very high criteria. So that the E-comic learning media is very effectively used as a medium for learning mathematics to increase student interest in learning during the Covid-19 pandemic.
\end{abstract}

Keywords: analysis, E-comic, social arithmetic, covid-1 pandemic 
Analisis Minat Belajar Siswa Menggunakan Media Pembelajaran E-comic Aritmatika Sosial Masa Pandemi Covid-19

Yosse Andreas Batu-Bara' ${ }^{1)}$, Zetriuslita ${ }^{2)}$, Agus Dahlia ${ }^{3)}$, Leo Adhar Effendi' ${ }^{4)}$

\section{PENDAHULUAN}

Pandemi Covid-19 menjadi trending topik pembicaraan satu tahun belakangan sampai saat ini, sehingga pandemi ini sudah tidak asing bagi kehidupan secara global. Covid-19 pertama kali di umumkan oleh pemerintah pada bulan Maret 2020 yang lalu, penularan Covid-19 begitu cepat dan menyebar hampir kesemua negara termasuk Indonesia, sehingga Badan Kesehatan Dunia (WHO) mengatakan wabah ini sebagai pandemi global di tanggal 11 Maret 2020 (Asmuni, 2020). Adanya pandemi Covid-19 mengakibatkan perubahan yang besar pada bidang pendidikan, seluruh tingkat pendidikan 'dipaksa' merubah sistem pembelajaran untuk dapat beradaptasi secara cepat melakukan pembelajaran dari rumah melalui media daring (online) (Atsani, 2020).

Sehingga pemerintah sendiri mengeluarkan kebijakan untuk Belajar Dari Rumah (BDR) dengan dilaksanakan nya pembelajaran jarak jauh (PJJ), seperti yang terdapat dalam UndangUndang No. 20 tahun 2003 pasal 1 ayat 15 bahwa pendidikan yang peserta didiknya terpisah dari pendidik dan pembelajarannya menggunakan berbagai sumber belajar melalui teknologi komunikasi, informasi dan media lain. Dalam proses pembelajaran jarak jauh (PJJ) itu sendiri terbagi menjadi dua pendekatan, yaitu pembelajaran jarak jauh dalam jaringan (daring) dan pembelajaran jarak jauh luar jaringan (luring) (Asmuni, 2020). Atas dasar kebijakan tersebut menjadi tantangan bagi guru untuk tetap dapat membuat proses pembelajaran yang menyenangkan, menarik dan efektif, walaupun pembelajaran tersebut harus dilaksanakan secara jarak jauh atau daring (Handayani \& Irawan, 2020). Walaupun proses pembelajaran dilaksanakan jarak jauh atau daring, guru harus mampu meningkatkan minat belajar dan keaktifan siswa. Keaktifan siswa itu sendiri dapat terbentuk melalui penerapan media pembelajaran yang menarik (Nurhayati, 2020). Ada satu cara yang dapat menarik minat siswa di masa pandemi Covid-19 yaitu dengan menggunakan media pembelajaran yang berbasis teknologi (Novilanti \& Suripah, 2021). Dimana kegiatan belajar sudah mulai dipengaruhi oleh perkembangan teknologi, proses pembelajaran di dalam kelas sebelumnya sudah di rancang atau digunakan dengan berbasis teknologi seperti media buku maupun multimedia seperti software, yang dapat mendukung proses pembelajaran (Ariawan \& Wahyuni, 2020).

Dengan kemajuan teknologi yang pesat dan membawa perubahan pada bidang pendidikan, menjadikan hal penting bagi pendidik dan peserta didik untuk belajar dan dapat menggunakan teknologi dalam pembelajaran (Zetriuslita et al., 2020). Di era revolusi industri 4.0 dalam kemajuan teknologi tidak perlu diragukan lagi, masyarakat dapat mengakses semuanya dengan menggunakan smartphone tanpa harus keluar rumah dan kemajuan teknologi ini membawa dampak pada bidang pendidikan juga (Zetriuslita et al., 2021). Sehingga perkembangan teknologi dan ilmu pengetahuan telah mengubah cara pandang dan berfikir secara praktis pada manusia secara global (Suripah, 2017). Pada kenyataannya penggunaan smartphone yang semakin canggih dan praktis juga mengubah daya gunanya sebagai alat bantu dalam memudahkan komunikasi dan sarana pembelajaran sehingga banyak disalah gunakan dan hanya digunakan sebagai media hiburan yang menghabiskan waktu saja, sedangkan dampak positif dari smartphone sebagai alat belajar cenderung meningkatkan produktivitas belajar ketika penggunaan dilakukan dengan sebaik mungkin (Kartika \& Arini, 2020). Disisi lain penggunaan media cetak berupa buku juga menyebabkan siswa kurang tertarik dalam pelajaran matematika, untuk itu peneliti ingin membuat media pembelajaran yang melibatkan penggunaan teknologi komputer dan smartphone.

Media pembelajaran adalah segala sesuatu yang dipakai untuk menyampaikan pesan atau informasi sehingga dapat merangsang perhatian dan minat siswa dalam proses belajar mengajar (Arsyad, 2016). Salah satu media pembelajaran yang menarik minat siswa dalam pembelajaran 
daring adalah memanfaatkan E-comic (komik elektronik) . E-comic menjadi media yang digemari oleh siswa dikarenakan dengan membaca komik atau buku-buku berkesan gambar dapat menarik perhatian siswa sehingga timbul imajinasi yang baik dalam berfikir siswa (Siregar et al., 2019). Komik adalah media pembelajaran berbentuk gambar yang disusun sedemikian rupa sehingga menarik. Dengan menggunakan komik sebagai media pembelajaran siswa lebih tertarik untuk membaca dan mempelajari konsep matematika yang bersifat abstrak (Pardimin \& Widodo, 2017). Komik juga merupakan lembar baca permanen yang mengarahkan pembacanya untuk menimbulkan rasa ingin tahu (Ntobuo et al., 2018). Ada satu cara dalam penyajian materi dengan menggunakan media pembelajaran sehingga lebih menarik dan mudah dipahami siswa yaitu dengan menggunakan E-comic (Farapatana et al., 2019). Hal ini dengan menggunakan media $E$-comic sebagai penyampai materi diharapkan agar pembaca merasa terhibur, menambah pengetahuan sehingga mendapatkan respon baik dari siswa (Purwitama, 2017).

Aritmatika sosial merupakan salah satu pokok bahasan dalam pelajaran matematika yang mempelajari operasi dasar suatu bilangan yang berkaitan dalam kehidupan sehari-hari yang mana cukup menarik bagi guru dan siswa jika disajikan dengan media E-comic (Friantini et al., 2020). Dengan menguasai konsep aritmatika sosial, siswa akan memiliki kemampuan memproleh, mengelola, dan memanfaatkan informasi untuk dapat menyelesaikan masalah dalam kehidupan sehari-hari. Dengan demikian media E-comic pada materi aritmatika sosial akan dirancang dengan berbantuan software flip PDF Profesional (Flip PDF Builer). Flip PDF Profesional merupakan software yang mempresentasi halaman flip untuk mengkonversi file PDF ke halaman- halaman berbentuk buku publikasi digital. Kemudian jika mengembangkan media pembelajaran menggunakan software ini dapat dipublish secara online maupun offline (Arsal et al., 2019). Sehingga memudahkan siswa untuk menggunakan media pembelajaran E-comic aritmatika sosial dengan smartphone mereka.

Dari penelitian yang dilakukan oleh Subroto et al., (2020) bahwa dengan menggunakan komik menjadikan pelajaran matematika pembelajaran yang efektif, selain itu beberapa peserta didik berpendapat bahwa dengan menggunakan komik, matematika menjadi pelajaran yang menyenangkan, siswa juga bersemangat dan tertarik mengikuti pembelajaran dan siswa juga memberikan pendapatnya bahwa karena materi dalam matematika diubah dalam bentuk kalimat sehari-hari, maka matematika menjadi lebih mudah dipahami dan dimengerti. Sedangkan hasil penelitian yang dilakukan oleh Siregar et al., (2019) juga menyimpulkan $E$ comic sebagai media pembelajaran matematika kelas VII SMP pokok bahasan aritmatika sosial kurikulum 2013 yang dikembangkan sangat efektif untuk digunakan dalam pembelajaran matematika.

Berdasarkan hasil beberapa penelitian yang telah dijabarkan, maka peneliti melakukan analisis terhadap penggunaan E-comic berbantuan software flip PDF Profesional (Flip PDF Builer) pada materi aritmatika sosial yang ditinjau dari aspek minat belajar siswa selama masa pandemi Covid-19. Tujuan dari penelitian ini untuk mendeskripsikan minat belajar siswa terhadap penggunaan E-comic berbantuan software flip PDF Profesional (Flip PDF Builer) pada materi aritmatika sosial.

\section{METODE PENELITIAN}

Penelitian ini merupakan penelitian kuantitatif yang dilakukan dengan menggunakan metode deskripsi kuantitatif. Penelitian ini bertujuan untuk mendeskripsikan minat belajar siswa terhadap penggunaan media E-comic berbantuan software flip PDF Profesional sebagai alternatif pembelajaran aritmatika sosial di masa pandemi Covid-19 secara deskriptif kuantitatif. Respon minat belajar siswa di deskripsikan dengan cara menghitung angket respon 
Analisis Minat Belajar Siswa Menggunakan Media Pembelajaran E-comic Aritmatika Sosial Masa Pandemi Covid-19

Yosse Andreas Batu-Bara' ${ }^{1)}$, Zetriuslita ${ }^{2)}$, Agus Dahlia ${ }^{3)}$, Leo Adhar Effendi' ${ }^{4}$

minat belajar siswa. Adapun respon minat belajar siswa terhadap penggunaan media $E$-comic berbantuan software flip PDF Profesional pada materi aritmatika sosial ditentukan dengan cara mengkonversikaan data angket respon minat belajar siswa kedalam data kuantitatif. Subjek penelitian sebanyak 15 orang siswa kelas VII SMP yang diambil secara random. Pada penelitian ini siswa dapat menggunakan media E-comic berbantuan software flip PDF Profesional pada materi aritmatika sosial dengan smartphone mereka.

Penelitian ini menggunakan instrumen non-test berupa angket minat belajar siswa. instrumen berupa angket respon minat belajar siswa dikonstruk berdasarkan indikatorindikator minat belajar sesuai kajian teori untuk membuat butir-butir pernyataan angket minat belajar siswa. Pada angket minat belajar siswa, peneliti memodifikasi empat indikator minat belajar siswa dari (Rohhadi, 2021) yaitu: (1) Perasaan senang; (2) Ketertarikan siswa; (3) Perhatian siswa; dan (4) Keterlibatan siswa, yang setiap indikator memiliki 5 pertanyaan, sehingga jumlah seluruh angket minat belajar siswa adalah 20 pernyataan, yang masing-masing terdiri dari 15 pernyataan positif dan 5 pernyataan negatif yang disebarkan menggunakan Google Form. Kategori skala minat belajar pernyataan positif yang digunakan dalam angket merupakan modifikasi dari skala likert, dan bentuk kategorinya terdiri dari empat pilihan, yaitu sangat setuju (4), setuju (3), dan tidak setuju (2), sangat tidak setuju (1) (Delviana et al., 2021). Sedangkan pada item skala minat pernyataan negatif yang digunakan sebaliknya dari skor penilaian pernyataan positif.

Teknik analisis data yang digunakan pada penelitian ini yaitu deskriptif kuantitatif dengan berbantuan Microsoft Excel. Pengolahan data dilakukan dengan cara menghitung persentase masing masing indikator minat belajar siswa yang terdiri dari perasaan senang, ketertarikan siswa, perhatian siswa, dan keterlibatan siswa. Setelah mendapatkan hasil dari analisis data, selanjutnya mengkategorikan angket minat belajar siswa sesuai tabel di bawah ini.

Tabel 1. Kriteria skor penilaian angket minat belajar

\begin{tabular}{|c|c|c|}
\hline No & Interval $(\%)$ & Kriteria \\
\hline 1 & $81-100$ & Sangat Tinggi \\
\hline 2 & $68-80$ & Tinggi \\
\hline 3 & $41-60$ & Cukup Tinggi \\
\hline 4 & $21-40$ & Kurang Tinggi \\
\hline 5 & $0-20$ & Kurang Tinggi Sekali \\
\hline
\end{tabular}

Sumber: Modifikasi (Arikunto, 2010)

\section{HASIL DAN PEMBAHASAN}

\section{Hasil}

Karena pembelajaran dilaksanakan secara daring maka penelitian dilaksanakan dengan share media pembelajaran E-comic yang berisi materi aritmatika sosial dengan berbantuan software flip PDF Profesional. Berikut adalah beberapa tampilan media E-comic materi aritmatika sosial yang ditampilkan menggunakan software flip PDF Profesional pada smartphone. 


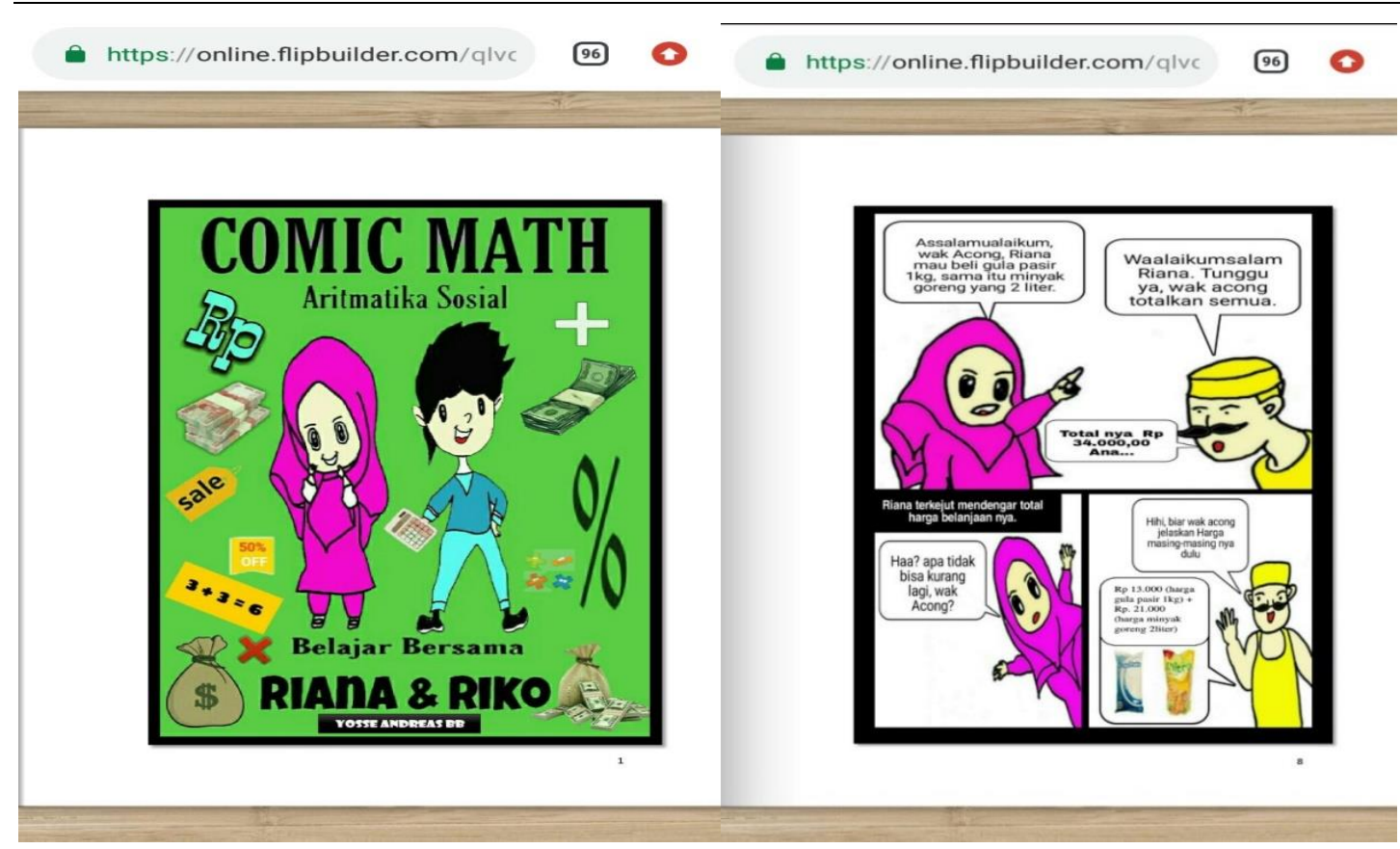

Gambar 1. Halaman cover E-comic aritmatika sosial dan salah satu halaman E-comic

Setelah siswa menggunakan media pembelajaran E-comic yang berisi materi aritmatika sosial dengan berbantuan software flip PDF Profesional dengan smartphone selanjutnya siswa diminta untuk mengisi untuk mengisi angket minat belajar yang terdiri dari 4 indikator yaitu (1) Perasaan senang; (2) Ketertarikan siswa; (3) Perhatian siswa; dan (4) Keterlibatan siswa, yang setiap indikator memiliki 5 pernyataan, yang masing-masing terdiri dari 15 pernyataan positif dan 5 pernyataan negatif yang disebarkan menggunakan Google Form. Berikut adalah hasil analisis minat belajar siswa berdasarkan ke 4 indikator dari instrumen non-test yang telah diisi oleh siswa:

\section{a. Indikator Perasaan Senang}

Hasil persentase tanggapan siswa terhadap indikator perasaan senang sebagaimana disajikan pada Tabel 2.

Tabel 2. Persentase respon siswa pada indikator perasaan senang

\begin{tabular}{|l|c|c|c|c|c|}
\hline \multicolumn{5}{|c|}{ Perasaan Senang } \\
\hline Jumlah Skor & 54 & 53 & 53 & 46 & 52 \\
\hline Total Skor Maksimal & 60 & 60 & 60 & 60 & 60 \\
\hline Persentase & $90 \%$ & $88,33 \%$ & $88,33 \%$ & $76,67 \%$ & $86,67 \%$ \\
\hline Rata-Rata & \multicolumn{5}{|c|}{$86 \%$} \\
\hline Kriteria & \multicolumn{7}{|c|}{ Sangat Tinggi } \\
\hline
\end{tabular}

Dari Tabel 2 terlihat bahwa persentase pada setiap pernyataan dari aspek perasaan senang yang terdiri dari 5 pernyataan mendapatkan hasil rata-rata dari ke-5 nya yaitu $86 \%$ dengan kriteria sangat tinggi. Sehingga dapat disimpulkan siswa sangat senang atau bersemangat dalam proses pembelajaran dengan menggunakan media pembelajaran E-comic yang berisi materi aritmatika sosial dengan berbantuan software flip PDF Profesional. 
Analisis Minat Belajar Siswa Menggunakan Media Pembelajaran E-comic Aritmatika Sosial Masa Pandemi Covid-19

Yosse Andreas Batu-Bara ${ }^{1)}$, Zetriuslita ${ }^{2)}$, Agus Dahlia ${ }^{3)}$, Leo Adhar Effendi ${ }^{4)}$

\section{b. Indikator Ketertarikan Siswa}

Hasil persentase tanggapan siswa terhadap indikator ketertarikan siswa sebagaimana disajikan pada Tabel 3.

Tabel 3. Persentase respon siswa pada indikator ketertarikan siswa

\begin{tabular}{|l|c|c|c|c|c|}
\hline \multicolumn{5}{|c|}{ Ketertarikan Siswa } \\
\hline Jumlah Skor & 50 & 48 & 48 & 49 & 48 \\
\hline Total Skor Maksimal & 60 & 60 & 60 & 60 & 60 \\
\hline Persentase & $83,33 \%$ & $80 \%$ & $80 \%$ & $81,67 \%$ & $80 \%$ \\
\hline Rata-Rata & \multicolumn{5}{|c|}{$81 \%$} \\
\hline Kriteria & \multicolumn{7}{|c|}{ Sangat Tinggi } \\
\hline
\end{tabular}

Dari Tabel 3 terlihat bahwa persentase pada setiap pernyataan dari aspek ketertarikan siswa yang terdiri dari 5 pernyataan mendapatkan hasil rata-rata dari ke-5 nya yaitu $81 \%$ dengan kriteria sangat tinggi. Sehingga dapat disimpulkan siswa sangat tertarik dan fokus dalam proses pembelajaran dengan menggunakan media pembelajaran E-comic yang berisi materi aritmatika sosial dengan berbantuan software flip PDF Profesional.

\section{c. Indikator Perhatian Siswa}

Hasil persentase tanggapan siswa terhadap indikator perhatian siswa sebagaimana disajikan pada Tabel 4.

Tabel 4. Persentase respon siswa pada indikator perhatian siswa

\begin{tabular}{|l|c|c|c|c|c|}
\hline \multicolumn{5}{|c|}{ Perhatian Siswa } \\
\hline Jumlah Skor & 50 & 45 & 47 & 43 & 42 \\
\hline Total Skor Maksimal & 60 & 60 & 60 & 60 & 60 \\
\hline Persentase & $83,33 \%$ & $75 \%$ & $78,33 \%$ & $71,67 \%$ & $70 \%$ \\
\hline Rata-Rata & \multicolumn{5}{|c|}{$75,67 \%$} \\
\hline Kriteria & \multicolumn{7}{|c|}{ Tinggi } \\
\hline
\end{tabular}

Dari Tabel 4 terlihat bahwa persentase pada setiap pernyataan dari aspek perhatian siswa yang terdiri dari 5 pernyataan mendapatkan hasil rata-rata dari ke-5 nya yaitu 75,65\% dengan kriteria tinggi. Sehingga dapat disimpulkan siswa sangat memperhatikan dan berminat dalam proses pembelajaran dengan menggunakan media pembelajaran E-comic yang berisi materi aritmatika sosial dengan berbantuan software flip PDF Profesional.

\section{d. Indikator Keterlibatan Siswa}

Hasil persentase tanggapan siswa terhadap indikator keterlibatan siswa sebagaimana disajikan pada Tabel 5 .

Tabel 5. Persentase respon siswa pada indikator keterlibatan siswa

\begin{tabular}{|l|c|c|c|c|c|}
\hline \multicolumn{5}{c|}{ Keterlibatan Siswa } \\
\hline Jumlah Skor & 48 & 47 & 49 & 48 & 48 \\
\hline Total Skor Maksimal & 60 & 60 & 60 & 60 & 60 \\
\hline Persentase & $80 \%$ & $78,33 \%$ & $81,66 \%$ & $80 \%$ & $80 \%$ \\
\hline Rata-Rata & \multicolumn{5}{|c|}{ Tinggi } \\
\hline Kriteria & \multicolumn{6}{|}{} \\
\hline
\end{tabular}

Dari Tabel 5 terlihat bahwa persentase pada setiap pernyataan dari aspek keterlibatan siswa yang terdiri dari 5 pernyataan mendapatkan hasil rata-rata dari ke-5 nya yaitu $80 \%$ 
dengan kriteria tinggi. Sehingga dapat disimpulkan siswa sangat terlibat dan mengerjakan latihan-latihan dalam proses pembelajaran dengan menggunakan media pembelajaran E-comic yang berisi materi aritmatika sosial dengan berbantuan software flip PDF Profesional.

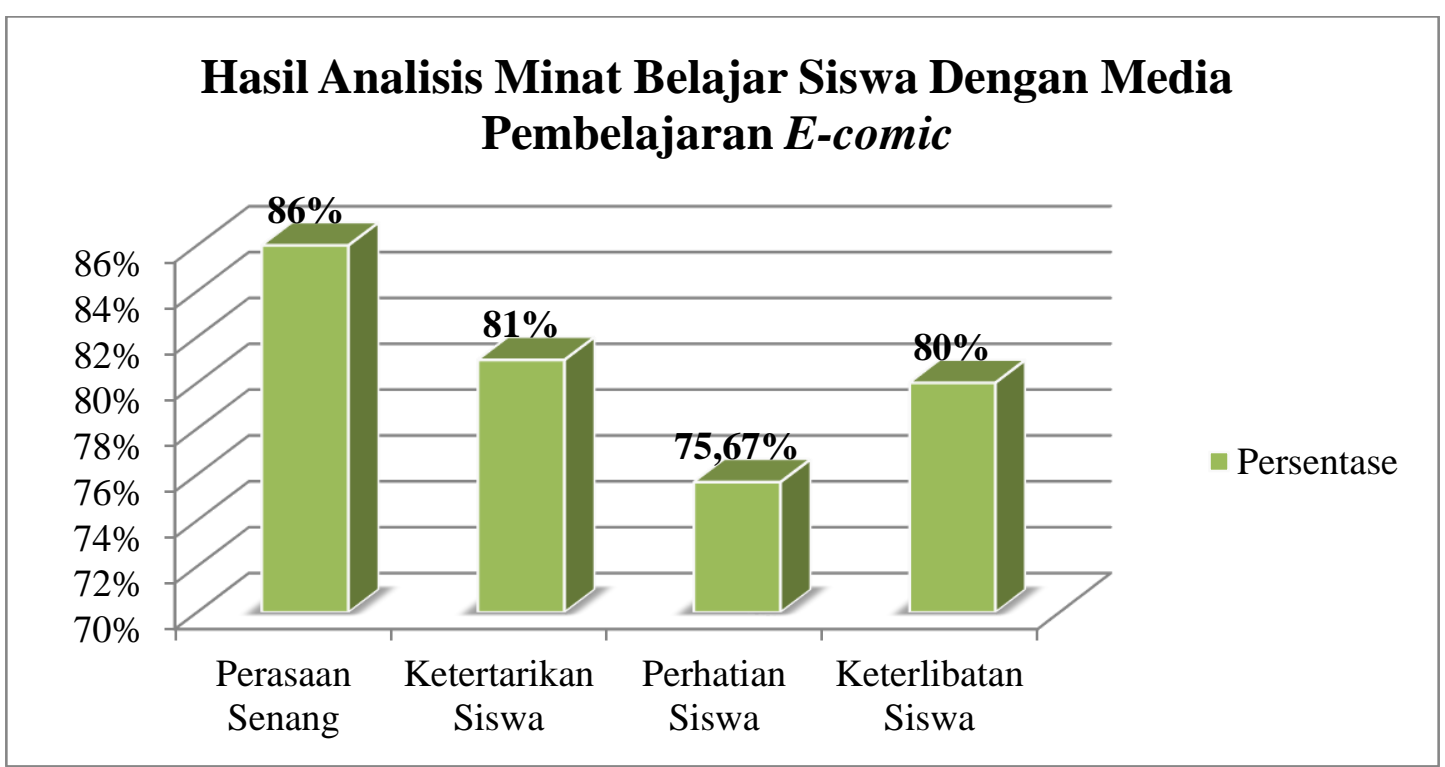

Gambar 2. Rangkuman hasil analisis minat belajar siswa dengan media pembelajaran E-comic ke-4 indikator

Berdasarkan data hasil penelitian yang telah dijabarkan bahwa setiap indikator minat belajar siswa yang terdapat pada angket tergolong baik. Hal ini menunjukkan respon positif siswa terhadap penggunaan media pembelajaran E-comic yang berisi materi aritmatika sosial dengan berbantuan software flip PDF Profesional. Hasil analisis minat belajar siswa dengan media pembelajaran E-comic pada materi aritmatika sosial berdasarkan ke empat indikator diperoleh rata-rata yaitu $80,67 \%$ sesuai dengan tabel kriteria skor penilaian angket minat belajar maka rata-rata analisis minat belajar siswa dengan media pembelajaran E-comic pada materi aritmatika sosial masuk kedalam kriteria sangat tinggi.

\section{Pembahasan}

Penelitian ini termasuk ke dalam penelitian kuantitatif yang dilakukan dengan metode deskriptif kuantitatif, karena penelitian ini memiliki tujuan yaitu untuk mendeskripsikan minat belajar siswa terhadap penggunaan media pembelajaran E-comic yang berisi materi aritmatika sosial dengan berbantuan software flip PDF Profesional. Analisis minat belajar siswa dilakukan dengan mengisi angket minat belajar dengan menggunakan Google Form yang mempertimbangkan 4 indikator yaitu (1) Perasaan senang; (2) Ketertarikan siswa; (3) Perhatian siswa; dan (4) Keterlibatan siswa, yang setiap indikator memiliki 5 pernyataan, yang masingmasing terdiri dari 15 pernyataan positif dan 5 pernyataan negatif.

Indikator perasaan senang yang terdiri dari 5 pernyataan bertujuan untuk melihat apakah siswa kelas VII SMP senang menggunakan media E-comic pada materi aritmatika sosial dan bersemangat saat belajar aritmatika sosial dengan menggunakan media $E$-comic karena bisa di akses dengan smartphone. Sehingga berdasarkan hasil penilaian dari indikator perasaan senang menghasilkan yaitu pernyataan pertama dengan persentase $90 \%$, pernyataan kedua $88,33 \%$, pernyataan ketiga $88,33 \%$, pernyataan keempat $76,67 \%$ dan pernyataan kelima $86,67 \%$ mendapatkan hasil rata-rata dari ke-5 nya yaitu $86 \%$ dengan kriteria sangat tinggi, hal ini 
Analisis Minat Belajar Siswa Menggunakan Media Pembelajaran E-comic Aritmatika Sosial Masa Pandemi Covid-19

Yosse Andreas Batu-Bara' ${ }^{1)}$, Zetriuslita ${ }^{2)}$, Agus Dahlia ${ }^{3)}$, Leo Adhar Effendi' ${ }^{4}$

dikarenakan adanya 2 kategori penilaian yang bernilai 2 yaitu tidak setuju, 30 kategori penilaian yang bernilai 3 yaitu setuju dan 35 kategori penilaian yang bernilai 4 yaitu sangat setuju. Sehingga dapat disimpulkan siswa sangat senang atau bersemangat dalam proses pembelajaran dengan menggunakan media pembelajaran E-comic yang berisi materi aritmatika sosial dengan berbantuan software flip PDF Profesional.

Indikator ketertarikan siswa yang terdiri dari 5 pernyataan bertujuan untuk melihat apakah siswa kelas VII SMP merasa tertarik menggunakan media E-comic pada materi aritmatika sosial dan fokus saat belajar aritmatika sosial dengan menggunakan media E-comic atau mungkin dengan sebalik nya merasa bosan. Sehingga berdasarkan hasil penilaian dari indikator ketertarikan siswa menghasilkan yaitu pernyataan pertama dengan persentase 83,33\%, pernyataan kedua $80 \%$, pernyataan ketiga $80 \%$, pernyataan keempat $81,67 \%$ dan pernyataan kelima $80 \%$ mendapatkan hasil rata-rata dari ke-5 nya yaitu $81 \%$ dengan kriteria sangat tinggi, hal ini dikarenakan adanya 57 kategori penilaian yang bernilai 3 yaitu setuju dan 18 kategori penilaian yang bernilai 4 yaitu sangat setuju. Sehingga dapat disimpulkan siswa sangat tertarik dan fokus dalam proses pembelajaran dengan menggunakan media pembelajaran E-comic yang berisi materi aritmatika sosial dengan berbantuan software flip PDF Profesional.

Indikator keterlibatan siswa yang terdiri dari 5 pernyataan bertujuan untuk melihat apakah siswa kelas VII SMP berani mengungkapkan pendapat, mengerjakan soal latihan yang ada pada media $E$-comic, dan bisa mengoperasikan media $E$-comic aritmatika sosial secara online. Sehingga berdasarkan hasil penilaian dari indikator keterlibatan siswa menghasilkan yaitu pernyataan pertama dengan persentase $83,33 \%$, pernyataan kedua $75 \%$, pernyataan ketiga $78,33 \%$, pernyataan keempat $71,67 \%$ dan pernyataan kelima $70 \%$ mendapatkan hasil rata-rata dari ke-5 nya yaitu $75,65 \%$ dengan kriteria tinggi, hal ini dikarenakan adanya 1 kategori penilaian yang bernilai 1 yaitu sangat tidak setuju, 13 kategori penilaian yang bernilai 2 yaitu tidak setuju, 41 kategori penilaian yang bernilai 3 yaitu setuju dan 19 kategori penilaian yang bernilai 4 . Sehingga dapat disimpulkan siswa sangat memperhatikan dan berminat untuk menggunakan media E-comic secara online dalam proses pembelajaran dengan menggunakan media pembelajaran E-comic yang berisi materi aritmatika sosial dengan berbantuan software flip PDF Profesional.

Indikator perhatian siswa yang terdiri dari 5 pernyataan bertujuan untuk melihat apakah siswa kelas VII SMP memperhatikan pembelajaran aritmatika sosial secara daring dengan media E-comic dari awal sampai akhir dan berminat untuk menggunakan media E-comic secara online atau mungkin dengan sebalik nya malas membuka media E-comic secara online. Sehingga berdasarkan hasil penilaian dari indikator perhatian siswa menghasilkan yaitu pernyataan pertama dengan persentase $80 \%$, pernyataan kedua $78,33 \%$, pernyataan ketiga $81,66 \%$, pernyataan keempat $80 \%$ dan pernyataan kelima $80 \%$ mendapatkan hasil rata-rata dari ke-5 nya yaitu $80 \%$ dengan kriteria tinggi, hal ini dikarenakan adanya 5 kategori penilaian yang bernilai 2 yaitu tidak setuju, 50 kategori penilaian yang bernilai 3 yaitu setuju dan 20 kategori penilaian yang bernilai 4 . Sehingga dapat disimpulkan siswa sangat terlibat dan mengerjakan latihan-latihan dalam proses pembelajaran dengan menggunakan media pembelajaran E-comic yang berisi materi aritmatika sosial dengan berbantuan software flip PDF Profesional.

Berdasarkan penelitian yang dilakukan oleh Subroto et al., (2020) bahwa dengan menggunakan komik menjadikan pelajaran matematika pembelajaran yang efektif, selain itu beberapa peserta didik berpendapat bahwa dengan menggunakan komik, matematika menjadi pelajaran yang menyenangkan. siswa juga bersemangat dan tertarik mengikuti pembelajaran dan siswa juga memberikan pendapatnya bahwa karena materi dalam matematika diubah dalam bentuk kalimat sehari-hari, maka matematika menjadi lebih mudah dipahami dan 
dimengerti sehingga minat belajar siswa dalam pelajaran matematika meningkat. Sedangkan hasil penelitian yang dilakukan oleh Siregar et al., (2019) juga menyimpulkan E-comic sebagai media pembelajaran matematika kelas VII SMP pokok bahasan aritmatika sosial kurikulum 2013 yang dikembangkan sangat efektif dan minat belajar siswa dalam pembelajaran matematika sangat tinggi.

Sehingga hasil penelitian ini menunjukkan bahwa dengan menerapkan media pembelajaran E-comic yang berisi materi aritmatika sosial dengan berbantuan software flip PDF Profesional dalam proses pembelajaran dapat menarik minat belajar siswa dalam proses pembelajaran. Selama proses pembelajaran terjadi, siswa memberikan respon yang sangat baik terhadap penggunaan media pembelajaran E-comic. Dengan demikian, dengan memanfaatkan media pembelajaran E-comic yang berisi materi aritmatika sosial dengan berbantuan software flip PDF Profesional dalam proses pembelajaran dapat memberikan dampak yang positif dan meningkatkan minat belajar siswa di masa pandemi Covid-19.

\section{KESIMPULAN}

Dalam proses pembelajaran matematika hendaknya tidak terfokus pada materi yang disampaikan saja tetapi juga harus adanya strategi dalam penggunaan media pembelajaran yang bervariasi yang dapat menarik minat belajar siswa pada proses pembelajaran contoh nya adalah dengan menggunakan media pembelajaran E-comic yang berisi materi aritmatika sosial dengan berbantuan software flip PDF Profesional. Hasil penelitian ini menunjukkan bahwa dengan menerapkan media pembelajaran $E$-comic yang berisi materi aritmatika sosial dengan berbantuan software flip PDF Profesional dalam proses pembelajaran dapat menarik minat belajar siswa dalam proses pembelajaran. Selama proses pembelajaran terjadi, siswa memberikan respon yang sangat baik terhadap penggunaan media pembelajaran E-comic. Dengan demikian, dengan memanfaatkan media pembelajaran E-comic yang berisi materi aritmatika sosial dengan berbantuan software flip PDF Profesional dalam proses pembelajaran dapat memberikan dampak yang positif dan meningkatkan minat belajar siswa di masa pandemi Covid-19.

Diharapkan pada penelitian selanjutnya hendaknya peneliti bisa membuat media pembelajaran E-comic seperti ini pada materi-materi matematika lain nya, perlu dikaji penggunaan media pembelajaran $E$-comic terhadap hasil belajar siswa pada materi matematika yang lainnya. Hal ini dimaksud agar media pembelajaran $E$-comic bukan hanya dapat diketahui pada materi aritmatika sosial saja, tetapi juga dapat pada materi matematika yang lainnya.

\section{REFERENSI}

Ariawan, R., \& Wahyuni, A. (2020). The effect of applying TPS type cooperative learning model assisted by SPSS software on students' skills in IT-based statistical data analysis course. Journal of Physics: Conference Series, 1581(1).

Arikunto, S. (2010). Manajemen Penelitian. Jakarta: Rineka Cipta.

Arsal, M., Danial, M., \& Hala, Y. (2019). Pengembangan Media Pembelajaran E-Modul Materi Sistem Peredaran Darah Pada Kelas XI MIPA SMAN 6 BARRU. Prosiding Seminar Nasional Biologi VI, 434-442.

Arsyad, A. (2016). Media Pembelajaran (19th ed.). PT Raja Grafindo Persada.

Asmuni. (2020). Problematika Pembelajaran Daring di Masa Pandemi Covid-19 dan Solusi Pemecahannya. Jurnal Paedagogy: Jurnal Penelitian Dan Pengembangan Pendidikan, 7(4), 281-288.

Atsani, L. G. M. Z. (2020). Transformasi Media Pembelajaran Pada Masa Pandemi Covid-19. Jurnal Teknologi Pendidikan, 22(1), 65-70. 
Analisis Minat Belajar Siswa Menggunakan Media Pembelajaran E-comic Aritmatika Sosial Masa Pandemi Covid-19

Yosse Andreas Batu-Bara' ${ }^{1)}$, Zetriuslita ${ }^{2)}$, Agus Dahlia ${ }^{3)}$, Leo Adhar Effendi ${ }^{4}$

Delviana, D., Supriadi, N., Wahyu, R., Putra, Y., \& E-learning, M. (2021). Pengembangan Media E-Learning Berbasis Schoology Sebagai Suplemen Pembelajaran. 8(1), 6070.

Farapatana, E., Anwar, Y. S., \& Abdillah, A. (2019). Pengembangan Komik Matematika dengan Metode Preview, Question, Read, Reflect, Recite, \& Review (PQ4R) Pada Materi Lingkaran Kelas VIII SMP. JTAM | Jurnal Teori Dan Aplikasi Matematika, $3(1), 01$.

Friantini, R. N., Winata, R., \& Permata, J. I. (2020). Kontekstual Aritmatika Sosial. Media Sains Indonesia.

Handayani, S. D., \& Irawan, A. (2020). Pembelajaran matematika di masa pandemic covid-19 berdasarkan pendekatan matematika realistik. Jurnal Math Educator Nusantara: Wahana Publikasi Karya Tulis Ilmiah Di Bidang Pendidikan Matematika, 6(2), 179189.

Kartika, \& Arini, T. (2020). (C) 2020 Jurnal Keperawatan. Jurnal Keperawatan, 1.

Novilanti, F. R. E., \& Suripah, S. (2021). Alternatif Pembelajaran Geometri Berbantuan Software GeoGebra di Masa Pandemi Covid-19. Jurnal Cendekia: Jurnal Pendidikan Matematika, 5(1), 357-367.

Ntobuo, N. E., Arbie, A., \& Amali, L. N. (2018). The Development Of Gravity Comic Learning Media Based On Gorontalo Culture. Jurnal Pendidikan IPA Indonesia, 7(2), 246251.

Nurhayati, E. (2020). Meningkatkan Keaktifan Siswa Dalam Pembelajaran Daring Melalui Media Game Edukasi Quiziz pada Masa Pencegahan Penyebaran Covid-19. Jurnal Paedagogy: Jurnal Penelitian Dan Pengembangan Pendidikan, 7(3), 145.

Pardimin, \& Widodo, S. A. (2017). Development comic based problem solving in geometry. International Electronic Journal of Mathematics Education, 12(3), 233-241.

Purwitama, A. N. (2017). Pengembangan Media Komik Pada Materi Arimatika Sosial Siswa SMP Kelas VII. Simki-Techsain, 01(01).

Rohhadi, W. (2021). Pengaruh Gaya dan Minat Belajar Terhadap Prestasi Belajar Ilmu Pengetahuan Sosial Siswa SMP Swasta di Kabupaten Bogor. Herodotus: Jurnal Pendidikan IPS, 3, 18-26.

Siregar, N., Suherman, S., Masykur, R., \& Ningtias, R. S. (2019). Pengembangan Media Pembelajaran E-Comic Dalam Pembelajaran Matematika. Journal of Mathematics Education and Science, 2(1), 11-19.

Subroto, E. N., Qohar, A., \& Dwiyana. (2020). Efektivitas Pemanfaatan Komik sebagai Media Pembelajaran Matematika. Jurnal Pendidikan: Teori, Penelitian, Dan Pengembangan, 5, 135-141.

Suripah. (2017). Mengembangkan Keterampilan Mengajar Berbasis ICT Bagi Calon Guru Abad XXI. Prosiding KMP Education Research Comference, 676-684.

Zetriuslita, Nofriyandi, \& Istikomah, E. (2020). The Effect Of Geogebra-Assisted Direct Instruction On Students' Self-Efficacy And Self-Regulation. Infinity Journal, 9(1), 41.

Zetriuslita, Nofriyandi, \& Istikomah, E. (2021). The Increasing Self-Efficacy and SelfRegulated through GeoGebra Based Teaching reviewed from Initial Mathematical Ability (IMA) Level. International Journal of Instruction, 14(1), 587-598. 